Article

\title{
Antibacterial Activity and Mechanisms of Essential Oil from Citrus medica L. var. sarcodactylis
}

\author{
Ze-Hua Li ${ }^{1,2}$, Ming Cai ${ }^{2, *}$, Yuan-Shuai Liu ${ }^{3}$, Pei-Long Sun ${ }^{2, *}$ and Shao-Lei Luo ${ }^{2}$ \\ 1 College of Biotechnology and Bioengineering, Zhejiang University of Technology, Hangzhou 310014, China; \\ 1111405109@zjut.edu.cn \\ 2 Department of Food Science and Technology, Zhejiang University of Technology, Hangzhou 310014, China; \\ 2111626030@zjut.edu.cn \\ 3 Department of Chemical and Biological Engineering, Hong Kong University of Science and Technology, \\ Hong Kong; bxxylzh@163.com \\ * Correspondence: sun_pl@zjut.edu.cn (P.-L.S.); caiming@zjut.edu.cn (M.C.); \\ Tel.: +86-0571-88320388 (P.-L.S.); +86-0571-88320345 (M.C.)
}

Academic Editor: Francesca Mancianti

Received: 29 March 2019; Accepted: 18 April 2019; Published: 22 April 2019

\begin{abstract}
In this work, antibacterial activity of finger citron essential oil (FCEO, Citrus medica L. var. sarcodactylis) and its mechanism against food-borne bacteria were evaluated. A total of 28 components in the oil were identified by gas chromatography-mass spectrometry, in which limonene $(45.36 \%), \gamma$-terpinene $(21.23 \%)$, and dodecanoic acid $(7.52 \%)$ were three main components. For in vitro antibacterial tests, FCEO exhibited moderately antibacterial activity against common food-borne bacteria: Escherichia coli, Staphylococcus aureus, Bacillus subtilis and Micrococcus luteus. It showed a better bactericidal effect on Gram-positive bacteria than Gram-negative. Mechanisms of the antibacterial action were investigated by observing changes of bacteria morphology according to scanning electron microscopy, time-kill analysis, and permeability of cell and membrane integrity. Morphology of tested bacteria was changed and damaged more seriously with increased concentration and exposure time of FCEO. FCEO showed a significant reduction effect on the growth rate of surviving bacteria and lead to lysis of the cell wall, intracellular ingredient leakage, and consequently, cell death.
\end{abstract}

Keywords: finger citron; essential oil; antibacterial; mechanism

\section{Introduction}

Food spoilage caused by microorganisms is always a main public health issue in our daily life. It leads to shelf life reduction, foodborne diseases, and economic loss in the food industry. For example, Staphylococcus aureus (S. aureus) is mainly responsible for food poisoning, toxic shock syndrome, endocarditis, and osteomyelitis [1]. In decades, synthetic additives have been widely used. However, the addition of synthetic preservatives is more restricted because of their toxic effects. Therefore, a strong interest in using natural substances for food preservation as an alternative has appeared. In recent years, essential oils have attracted lots of scientific interests because they exhibit a wide spectrum of bioactivities, such as antibacterial, antifungal, antiviral, antioxidant, and insecticidal activities [2,3].

Finger citron essential oil (FCEO) is a well-known oil with pleasant odor and flavor intensity, obtained from the epicarp and mesocarp of the fresh fruit of Citrus medica L. var. sarcodactylis. Nowadays, FCEO is in great demand in pharmaceutical, food, perfumery, and cosmetic industries. It has proven its analgesic, anxiolytic, neuroprotective effects and antimicrobial efficacy against bacteria and molds [4,5]. However, to the best of our knowledge, few have reported on the action mechanisms of FCEO on the growth inhibition of microorganisms. 
The aim of this study is to demonstrate the compositions of FCEO, evaluate its antibacterial activity, and explore its mechanisms of antibacterial action against two respective food-borne microorganisms by scanning electron microscope (SEM), time-kill analysis, and cell membrane permeability, as well as the integrity of the cell membrane.

\section{Results and Discussion}

\subsection{Chemical Characterization of FCEO}

28 compounds were identified by gas chromatography-mass spectrometry (GC-MS), including 16 monoterpenoid hydrocarbons, 8 sesquiterpenoid hydrocarbons, 3 acids, and 1 ester, as shown in Table 1. Main components of the oil were limonene $(45.36 \%), \gamma$-terpinene $(21.23 \%)$, and dodecanoic acid $(7.52 \%)$. Limonene widely exists in lemon and other citrus fruits. Linalool, $0.47 \%$, in the oil, is the main component for characteristic aroma of citrus, with a pleasant odor and mainly separated from scented herbs, rosewood, and citrus. Moreover, linalool is a chemical intermediate to yield vitamin E, hypotensive, perfumed product and cleaning agent. Most studies indicate that FCEO contains the major components limonene (33.8\% 57.7\%) and $\gamma$-terpinene (22.4\% 33.7\%), along with 3-carene, $\alpha$-pinene, $\beta$-pinene, $\alpha$-thujone, and terpinolene [6]. Russo et al. [7] reported FCEO comprised monoterpene and sesquiterpene hydrocarbons (limonene, $\gamma$-terpinene) and oxygenated derivatives (linalool, linalyl acetate). However, the ratio of these components in the oil compared with the published data were different. Various factors could affect the concentrations, such as harvest time, geographic origin, and agro-climatic conditions of the regions.

Table 1. Components of the essential oil from finger citron.

\begin{tabular}{|c|c|c|c|c|c|}
\hline No. & Compound & $\mathrm{RI}^{\mathrm{a}}$ & RI (lab) ${ }^{b}$ & Area $\%$ & CAS No. \\
\hline 1 & $\alpha$-Pinene & 944 & 948 & 1.42 & $80-56-8$ \\
\hline 2 & 3-Carene & 951 & 950 & 0.69 & $13466-78-9$ \\
\hline 3 & $\beta$-Pinene & 953 & 956 & 1.15 & $127-91-3$ \\
\hline 4 & $\beta$-Myrcene & 980 & 979 & 0.81 & $123-35-3$ \\
\hline 5 & $\alpha$-phellandrene & 983 & 983 & 0.63 & $99-83-2$ \\
\hline 6 & Allo-ocimene & 998 & 993 & 0.24 & $673-84-7$ \\
\hline 7 & $\alpha$-Terpinene & 1011 & 1008 & 0.56 & $99-86-5$ \\
\hline 8 & Limonene & 1021 & 1020 & 45.36 & $138-86-3$ \\
\hline 9 & cis- $\beta$-Ocimene & 1024 & 1024 & 0.38 & $3338-55-4$ \\
\hline 10 & $\gamma$-Terpinene & 1045 & 1047 & 21.23 & $99-85-4$ \\
\hline 11 & Linalool & 1080 & 1081 & 0.47 & $78-70-6$ \\
\hline 12 & Terpinen-4-ol & 1134 & 1137 & 2.35 & $562-74-3$ \\
\hline 13 & $\alpha$-Terpineol & 1168 & 1172 & 2.51 & $98-55-5$ \\
\hline 14 & Geranial & 1173 & 1174 & 0.05 & $141-27-5$ \\
\hline 15 & Carveol & 1203 & 1206 & 0.35 & $99-48-9$ \\
\hline 16 & Neral & 1212 & 1214 & 0.04 & $106-26-3$ \\
\hline 17 & Geranyl acetate & 1353 & 1352 & 0.15 & $105-87-3$ \\
\hline 18 & $\alpha$-Bergamotene & 1427 & 1427 & 1.42 & $17699-05-7$ \\
\hline 19 & $\delta$-Cadinene & 1439 & 1440 & 0.35 & $483-76-1$ \\
\hline 20 & Germacrene D & 1480 & 1480 & 0.7 & $23986-74-5$ \\
\hline 21 & Caryophyllene & 1500 & 1494 & 1.6 & $87-44-5$ \\
\hline 22 & $\gamma$-Muurolene & 1496 & 1494 & 0.19 & $30021-74-0$ \\
\hline 23 & $\beta$-Bisabolene & 1500 & 1500 & 3.23 & $495-61-4$ \\
\hline 24 & Dodecanoic acid & 1571 & 1570 & 7.52 & $143-07-7$ \\
\hline 25 & Humulene & 1581 & 1579 & 0.3 & $6753-98-6$ \\
\hline 26 & $\alpha$-Bisabolol & 1686 & 1683 & 1.37 & $515-69-5$ \\
\hline 27 & Tetradecanoic acid & 1769 & 1769 & 2.85 & $544-63-8$ \\
\hline 28 & $\begin{array}{l}\text { Hexadecanoic acid } \\
\text { Total }\end{array}$ & 1970 & 1968 & $\begin{array}{c}1.46 \\
99.38\end{array}$ & $57-10-3$ \\
\hline
\end{tabular}

a: Data were obtained from experiments. b: Data were obtained from NIST 2.0 version of the library. 


\subsection{Antibacterial Activity of FCEO}

\subsubsection{Effects of FCEO on Bacteria}

According to previously published studies, diameters of inhibition zone (DIZ) were appreciated as follows: Not sensitive (diameter $\leq 8.0 \mathrm{~mm}$ ), moderately sensitive $(8.0<$ diameter $<14.0 \mathrm{~mm})$, sensitive $(14.0<$ diameter $<20.0 \mathrm{~mm}$ ), and extremely sensitive (diameter $\geq 20.0 \mathrm{~mm})$ [8]. The results showed the essential oil had certain antibacterial activity on all of the tested pathogens, with DIZ of the maximum value for S. aureus (19.2 $\pm 2.1 \mathrm{~mm}$ ), followed by Bacillus subtilis (B. subtilis, $16.3 \pm 1.3 \mathrm{~mm})$, Micrococcus luteus (M. luteus, $16.1 \pm 0.4 \mathrm{~mm}$ ) and Escherichia coli (E. coli, $11.2 \pm 0.9 \mathrm{~mm})$, as shown in Table 2. On the contrary, limonene exhibited moderate antibacterial activity. Van Vuuren and Viljoen [9] found that the antibacterial effect of limonene could be enhanced in the essential oil, compared with being used alone. It indicated that a synergistic effect might occur in the oil and thus potentiate its biological activity. Indeed, an advantageous synergistic effect of the essential oils constituents has often been observed [8]. Moreover, the oil showed better activity against Gram-positive bacteria than Gram-negative bacteria. It might be attributed to the structure of the bacterial membrane that Gram-negative bacteria possess an outer membrane with the presence of lipopolysaccharide molecules, which provide a hydrophilic surface [10]. The surface acts as a penetration barrier that blocks macromolecules and hydrophobic compounds penetrate into the target cell membrane [11]. Accordingly, Gram-negative bacteria are relatively resistant to hydrophobic antibiotics.

Table 2. The antibacterial ability of finger citron essential oil (FCEO) against different microorganisms.

\begin{tabular}{|c|c|c|c|c|c|c|c|c|c|}
\hline \multirow[t]{2}{*}{ Microorganisms } & \multicolumn{3}{|c|}{ DIZ * (mm) } & \multicolumn{3}{|c|}{ MIC (mg/mL) } & \multicolumn{3}{|c|}{ MBC $(\mathrm{mg} / \mathrm{mL})$} \\
\hline & FCEO & Limonene & Ciprofloxacin & FCEO & Limonene & Ciprofloxacin & FCEO & Limonene & Ciprofloxacin \\
\hline \multicolumn{10}{|l|}{ Gram-positive } \\
\hline B. subtilis & $16.3 \pm 1.3^{b}$ & $10.8 \pm 1.2^{\mathrm{ab}}$ & $23.7 \pm 0.6^{\mathrm{a}}$ & 0.625 & 1.25 & 0.001 & 2.5 & 1.25 & 0.001 \\
\hline S. aureus & $19.2 \pm 2.1^{\mathrm{a}}$ & $11.2 \pm 1.0^{\mathrm{a}}$ & $25.0 \pm 0.3^{\mathrm{a}}$ & 0.625 & 0.625 & 0.001 & 1.25 & 1.25 & 0.001 \\
\hline M. luteus & $16.1 \pm 0.4^{b}$ & $9.3 \pm 0.6^{b c}$ & $21.7 \pm 1.4^{\mathrm{b}}$ & 1.25 & 2.5 & 0.001 & 1.25 & 5 & 0.001 \\
\hline \multicolumn{10}{|l|}{ Gram-negative } \\
\hline E. coli & $11.2 \pm 0.9^{\mathrm{c}}$ & $8.6 \pm 0.6^{c}$ & $19.3 \pm 0.9^{c}$ & 2.5 & 1.25 & 0.001 & 2.5 & 1.25 & 0.002 \\
\hline
\end{tabular}

* Values represent means of three independent replicates \pm SD. Different letters within a column indicate statistically significant differences $(p<0.05)$ for DIZ.

\subsubsection{Minimal Inhibitory Concentration (MIC) and Minimum Bactericidal Concentration (MBC)}

FCEO is a bacterial inhibitor and bactericide against four tested bacteria. MICs and MBCs were in the range of $0.625 \sim 2.5 \mathrm{mg} / \mathrm{mL}$ and $1.25 \sim 2.5 \mathrm{mg} / \mathrm{mL}$, respectively, as shown in Table 2. FCEO exhibited the best bactericidal activity against $S$. aureus, with both minimum MIC and MBC. Gram-positive bacteria showed more sensitive than Gram-negative bacteria, which was in accordance with the results of DIZ. These results were similar with other researchers that citrus essential oil inhibited S. aureus, B. subtilis, and E. coli with MICs of $1 \%, 2 \%$ and $2 \%(v / v)$, respectively [12]. In contrast, Ghabraie et al. [13] tested bergamot essential oil against E. coli and S. aureus with MIC of 1.25 and $2.5 \mathrm{mg} / \mathrm{mL}$, respectively. The antibacterial activity of FCEO might attribute to monoterpene, alcohol, phenols, and other minor compounds. It has been reported that limonene possessed antibacterial, antiviral, antifungal and antioxidant activities, as mentioned in 2.2.1, while linalool and linalyl acetate exhibited antibacterial and antiviral activities [2]. Minor components possibly produce a synergistic effect to inhibit microorganisms as well. These results indicate FCEO is a potential bacterial inhibitor with a broad antibacterial spectrum, but the mechanisms of the antibacterial action need further study.

\subsection{Antibacterial Mechanisms of FCEO Against E. coli and S. aureus}

\subsubsection{The Effect of FCEO on Morphological Change}

Bacteria were treated with FCEO at concentrations of MIC and $2 \times \mathrm{MIC}$, respectively; untreated bacteria were set as control. Morphological changes of both treated and untreated bacteria were 
investigated by SEM. The results were shown in Figure 1. Untreated E. coli, as shown in Figure 1A, exhibited distinctive features characterized by regular rod-shaped, intact surface and striated cell walls. In contrast, most of the treated bacteria became irregular and shriveled of different degree, as shown in Figure 1B,C. Moreover, cell walls of the tested bacteria treated at $2 \times \mathrm{MIC}$ level showed more severe morphological destruction than those at a concentration of MIC. Untreated S. aureus cells, as shown in Figure 1D, were spherical, regular and intact and have a smooth surface. When exposed to FCEO for $4 \mathrm{~h}$, the cell membranes were pitted and shriveled, with holes on the surface, as shown in Figure 1E,F. In addition, bacterial aggregation could be observed. The changes of tested bacteria were due to the effect of FCEO, which could cause the destruction of the cell membrane of E. coli and S. aureus and the losses of intracellular materials. Microbial organisms were killed probably because the cytoplasmic membrane was disrupted or permeated through an interfacial contacting inhibitory effect that occurred on the surface of microspheres [11]. Both tested bacteria showed the essential oil-induced deformation of target cells occurred in a dose-dependent manner, which was also supported by other studies [14].

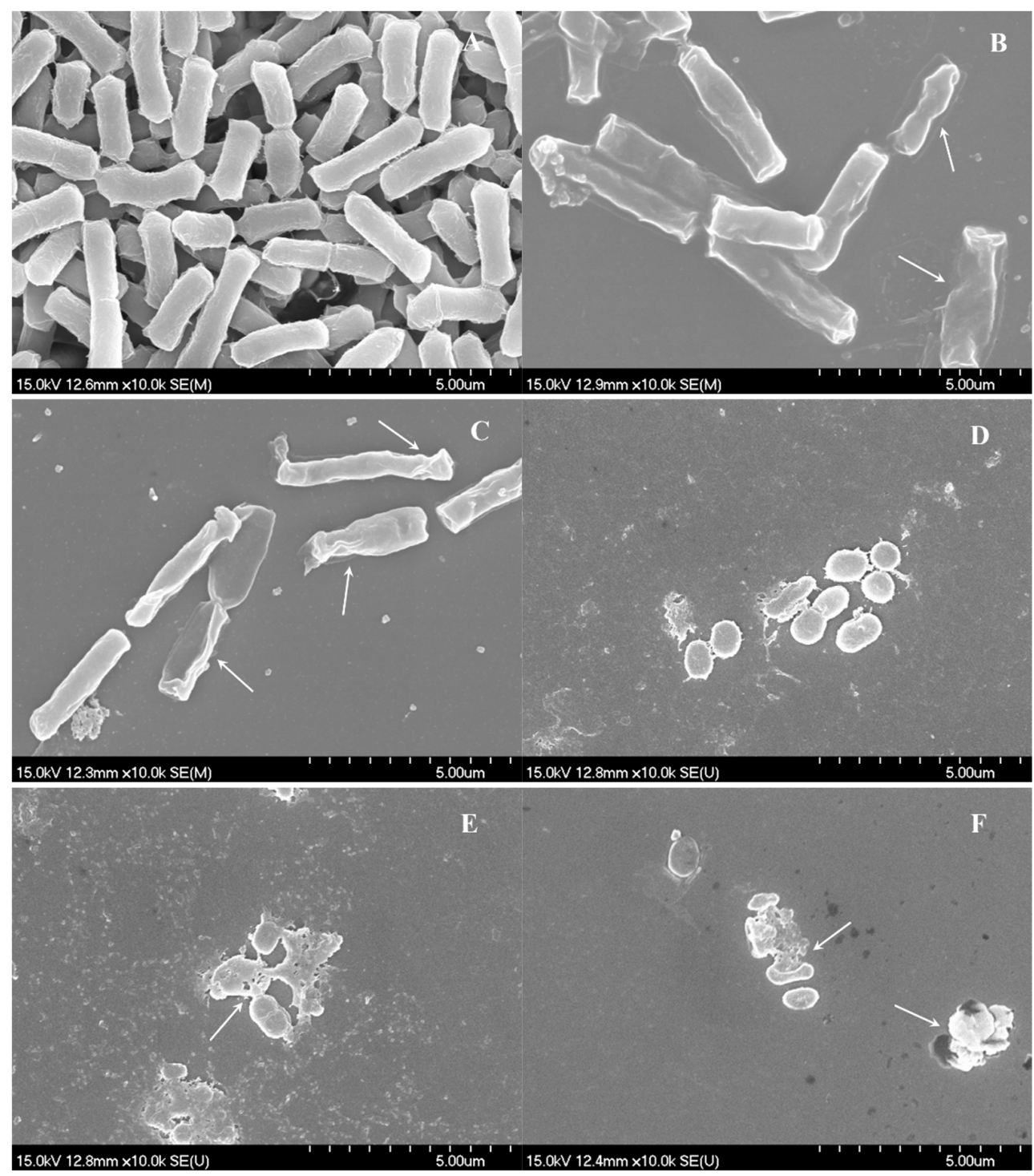

Figure 1. Effects of FCEO on morphological changes of E. coli and S. aureus. (A): Untreated E. coli; (B): E. coli treated with FCEO at minimal inhibitory concentration (MIC); (C): E. coli treated with FCEO at $2 \times$ MIC; (D): Untreated S. aureus; (E): S. aureus treated with FCEO at MIC; (F): S. aureus treated with $\mathrm{FCEO}$ at $2 \times \mathrm{MIC}$. Arrows show the shriveled appearance and holes on the cell surface. 


\subsubsection{Effect of FCEO on the Viability}

In order to evaluate the inactivation kinetics of FCEO, time-kill assays were performed, expressed as a logarithm of viable counts in Figure 2. Untreated E. coli increased from 5.1 to $8.3 \times \log _{10} \mathrm{CFU} / \mathrm{mL}$ and transited into stationary phase after $6 \mathrm{~h}$. Treated bacteria decreased sharply in the first $4 \mathrm{~h}$ and maintained steadily at about $2.5 \times \log _{10} \mathrm{CFU} / \mathrm{mL}$. The inhibition rate of $E$. coli reached $99.7 \%$ with the existence of essential oil at the concentration of MIC. The curve of tested E. coli at $2 \times \mathrm{MIC}$ level was similar to that at MIC. Untreated S. aureus increased from 5.5 to $8.3 \times \log _{10} \mathrm{CFU} / \mathrm{mL}$ in the cultivation time of $8 \mathrm{~h}$. Afterward, the number of viable cells kept stable and slowly decreased to $7.8 \times \log _{10}$ $\mathrm{CFU} / \mathrm{mL}$ after $24 \mathrm{~h}$. Compared with the control, treated S. aureus decreased significantly. In the first $2 \mathrm{~h}$, the numbers of viable cells of $S$. aureus treated at MIC and $2 \times \mathrm{MIC}$ both decreased to approximately $2.4 \times \log _{10} \mathrm{CFU} / \mathrm{mL}$ and maintained stable. The results showed FCEO had a fast killing effect on growth of $S$. aureus, with a bactericidal effect after $2 \mathrm{~h}$ of incubation, whereas $4 \mathrm{~h}$ for E. coli to achieve a lethal effect. This result was in accordance with the results of SEM that $S$. aureus was more sensitive than E. coli.

A



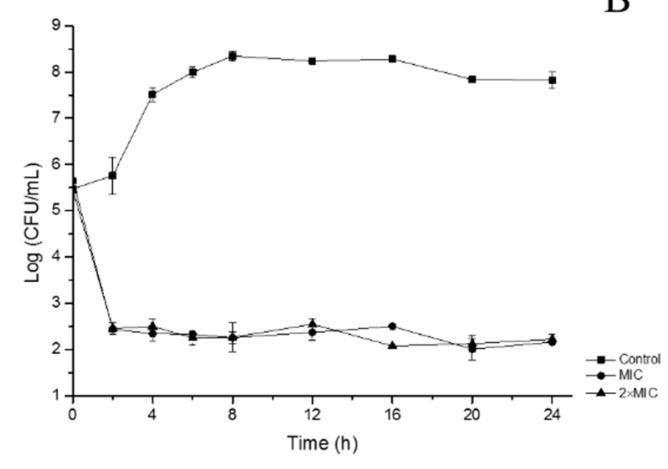

Figure 2. Time-kill analysis of E. coli and S. aureus. (A): E. coli; (B): S. aureus.

\subsubsection{The Effect of FCEO on Cell Membrane Permeability}

Cell membrane permeability was determined as the relative electric conductivity. As shown in Figure 3A, the relative electric conductivity of the control slightly increased. It might be because of normal lysis and death of the bacteria. On the contrary, the electric conductivity of tested E. coli increased rapidly in the first hours. The growth speed trended to slow down after about $11 \mathrm{~h}$. At the end of the assay, the relative conductivity of bacteria at concentrations of MIC and $2 \times$ MIC reached $37.04 \pm 3.60 \%$ and $46.05 \pm 2.64 \%$, respectively, compared with $4.94 \pm 0.58 \%$ of control. It showed relative electric conductivity of tested bacteria increased with the oil concentration and treatment time increasing. Similar trends were observed for $S$. aureus, but it showed higher conductivity than that of E. coli. After exposed to oil for $12 \mathrm{~h}$, the relative conductivity of S. aureus at the control, MIC, and $2 \times$ MIC were $10.01 \pm 1.66 \%, 63.98 \pm 3.00 \%$, and $80.59 \pm 3.65 \%$, respectively. It showed leakage of electrolytes occurred because of disruption of cell permeability caused by FCEO. Cells depend on cytoplasmic membrane to block small ions and keep normal metabolism, including solute transport, management of turgor pressure and motility [15]. Hence, even minor variations to the structure of the membrane can dramatically affect cell metabolism and result in death [16]. Essential oil can increase the permeability of bacteria membrane, leading to leakage of the intracellular ingredient. According to previous studies, phenolic existing in the FCEO can disrupt the cell membrane, interfere with cellular energy (ATP) generation system, and disrupt the proton motive force, eventually cause leakage of internal contents of the cell $[17,18]$. 
A



B

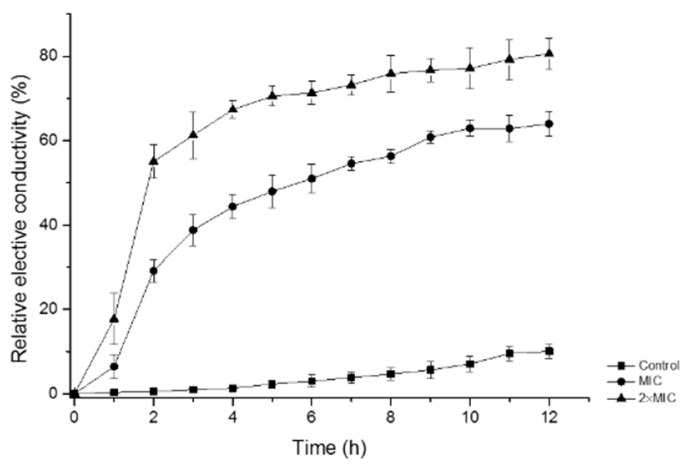

Figure 3. Effects of FCEO on the permeability of E. coli and S. aureus. (A): E. coli; (B): S. aureus.

\subsubsection{The Effect of FCEO on Integrity of the Cell Membrane}

Proteins and nucleic acids are extremely important macromolecules for cells referring to cellular structure and genetic information [19]. Determination of absorbance at $260 \mathrm{~nm}$ for nucleic acid and proteins is an indicator of membrane integrity [20]. Figure 4 shows the effects of essential oil on the integrity of cell membrane at MIC and $2 \times$ MIC concentrations for $7 \mathrm{~h}$, respectively. The absorbance values of $E$. coli increased significantly from $0.177 \pm 0.025$ to $0.817 \pm 0.032$ at MIC and $0.280 \pm 0.017$ to $0.920 \pm 0.026$ at $2 \times \mathrm{MIC}$, while the control increased from $0.043 \pm 0.010$ to $0.351 \pm 0.010$. Release of cell constituents increased significantly with the time and increased concentrations of FCEO. For S. aureus, during the period of treatment, absorbance values were in the range of $0.067 \pm 0.008 \sim 0.338 \pm 0.021$, $0.237 \pm 0.021 \sim 0.770 \pm 0.046$ and $0.267 \pm 0.015 \sim 0.900 \pm 0.036$ for oil concentration at the control, MIC, and $2 \times \mathrm{MIC}$, respectively. This result indicates FCEO can affect the integrity of the membrane, leading to the leakage of nucleic acids and proteins through the membrane, and consequently, cell death. Another probability is that essential oil penetrates through cytoplasmic membrane and especially damages mitochondrial membranes, and after that, the mitochondria produce free radicals, which oxidize and damage lipids, proteins and DNA [21].

$\mathrm{A}$

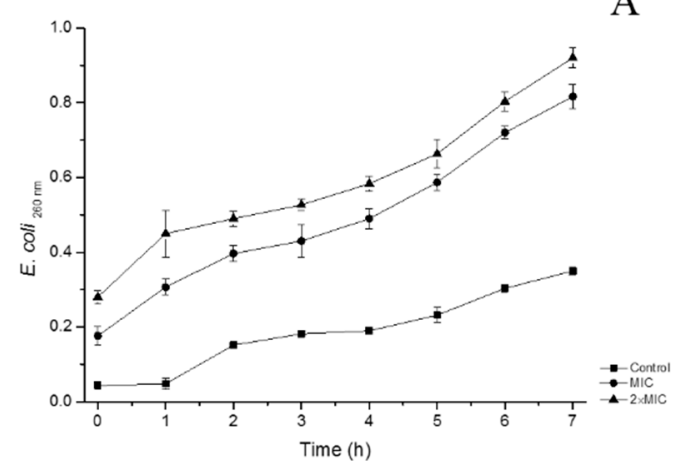

B

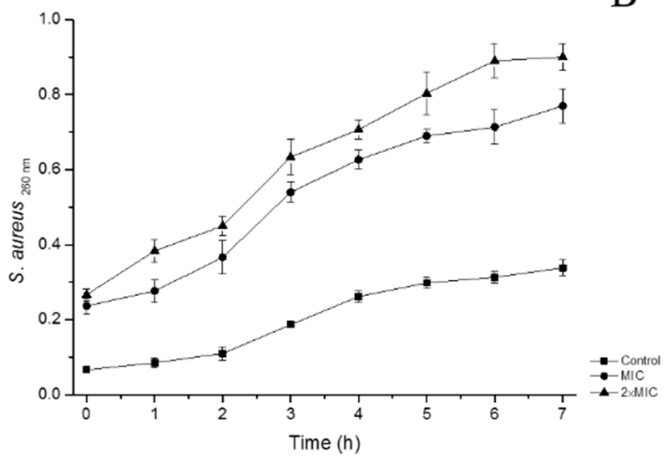

Figure 4. Effects of FCEO on the integrity of cell membrane of E. coli and S. aureus. (A): E. coli; (B): S. aureus.

\section{Materials and Methods}

\subsection{Materials}

Fresh finger citrons were purchased from Jisobo Biological Technology Co., Ltd, Jinhua, Zhejiang Province, China. The fruits were ground and hydro-distillated by using a Clevenger-type apparatus for $3 \mathrm{~h}$. The distillate was dried with anhydrous sodium sulfate overnight and stored at $4{ }^{\circ} \mathrm{C}$ in dark for further use. The essential oil obtained from finger citron was light yellow with a yield of $0.9 \%$. 


\subsection{Chemicals and Microorganisms}

Ciprofloxacin, standard substance of limonene, nutrient agar (NA), nutrient broth (NB) and Mueller Hinton agar (MHA) medium were purchased from Aladdin Industrial Corporation (Shanghai, China). Dimethyl sulfoxide (DMSO), glutaraldehyde, tertiary butyl alcohol, and glucose were from Macklin Biochemical Co., Ltd (Shanghai, China). Anhydrous sodium sulfate, sodium chloride, sodium dihydrogen phosphate $\left(\mathrm{NaH}_{2} \mathrm{PO}_{4} \cdot 2 \mathrm{H}_{2} \mathrm{O}\right)$, disodium hydrogen phosphate $\left(\mathrm{Na}_{2} \mathrm{HPO}_{4} \cdot 12 \mathrm{H}_{2} \mathrm{O}\right)$, diethyl ether, methanol and ethanol used were of analytical grade.

Three Gram-positive bacterial strains (Bacillus subtilis ATCC 6633, Staphylococcus aureus ATCC 6538 and Micrococcus luteus ATCC 4698) and 1 Gram-negative bacterial strain (Escherichia coli ATCC 25922) were obtained from China Center of Industrial Culture Collection (CICC). Bacterial strains were cultured at $37^{\circ} \mathrm{C}$ on MHA.

\subsection{GC-MS Analysis}

Analysis of essential oil was carried out using GC-MS (Trace 1300 Gas Chromatograph equipped with an ISQ LT Single Quadrupole Mass Spectrometer Thermo Fisher Scientific, Waltham, MA USA). GC-MS analysis was performed in the electron impact ionization mode $(70 \mathrm{eV})$ with $\mathrm{m} / z$ range $50 \sim 500 \mathrm{u}$. Temperatures of the injector and ion source were set at 250 and $280^{\circ} \mathrm{C}$, respectively. TG-5 MS AMINE GC Column $(30 \mathrm{~m} \times 0.25 \mathrm{~mm} \times 0.25 \mu \mathrm{m})$ was used. The oven temperature was programmed as follows: Initial oven temperature was $50^{\circ} \mathrm{C}$, holding for $1 \mathrm{~min}$, then raised to $130^{\circ} \mathrm{C}$ at $5{ }^{\circ} \mathrm{C} / \mathrm{min}$, holding for $0.5 \mathrm{~min}$, then to $250^{\circ} \mathrm{C}$ at $15^{\circ} \mathrm{C} / \mathrm{min}$, holding for $10 \mathrm{~min}$. Carrier gas was helium at a constant flow rate of $1.0 \mathrm{~mL} / \mathrm{min}$. The essential oil was diluted in ethanol of 1:500 before analysis and was injected $1.0 \mu \mathrm{L}$ into gas chromatograph with a split ratio of 10:1. EO constituents were identified by retention indices (RI) and NIST 2.0 version of the library [22].

\subsection{Evaluation of Antibacterial Activity of FCEO}

\subsubsection{Antibacterial Activity of FCEO}

Antibacterial activity of essential oil and its main component limonene were tested using agar diffusion method with some modifications [23]. Briefly, $100 \mu \mathrm{L}$ bacterial suspension (approximately $1 \times 10^{7} \mathrm{CFU} / \mathrm{mL}$ ) was spread on NA medium. A sterile filter paper disc (diameter $=6 \mathrm{~mm}$ ) containing $5 \mu \mathrm{L}$ of the sample was placed on the surface of plate. Incubating at $37^{\circ} \mathrm{C}$ for $24 \mathrm{~h}$, all the plates were observed for zones of growth inhibition and the diameters in millimeters of these zones were measured. Ciprofloxacin was used in parallel experiments as a positive control.

\subsubsection{Determination of MIC and MBC}

MIC was determined by the method of Silveira et al. [24] with a few modifications. Briefly, the stock of sample was diluted in 5\% $(v / v)$ DMSO. No detrimental effect on bacterial growth was observed at this concentration. Two-fold serial dilutions of samples were prepared in sterile NB ranging from $0.039-10 \mathrm{mg} / \mathrm{mL}$. Afterward, $180 \mu \mathrm{L}$ solution was mixed with $20 \mu \mathrm{L}$ bacterial suspension (approximately $10^{7} \mathrm{CFU} / \mathrm{mL}$ ) in the 96-well plates. A negative control test containing inoculated broth only supplemented with DMSO and a positive control containing Ciprofloxacin were also performed. The plates were incubated at $37^{\circ} \mathrm{C}$ for $24 \mathrm{~h}$. MBC was measured by subculture of $50 \mu \mathrm{L}$ from each well with no visible bacterial growth on NA plates after incubating at $37^{\circ} \mathrm{C}$ for $24 \mathrm{~h}$.

\subsection{Demonstration of Antibacterial Mechanisms of FCEO}

\subsubsection{SEM Analysis of Morphological Changes}

SEM was used to observe the morphological changes according to the method described by Bajpai, Sharma, and Baek [20] with a few modifications. The bacteria were incubated in NB medium at $37^{\circ} \mathrm{C}$ for $8 \mathrm{~h}$ and centrifuged $5000 \mathrm{r} / \mathrm{min}$. The cells were resuspended with phosphatic buffer solution (PBS, 
$0.1 \mathrm{M}, \mathrm{pH}$ 7.4) of approximately $10^{8} \mathrm{CFU} / \mathrm{mL}$. The suspension mixed with essential oil at different concentrations of the control, MIC, and $2 \times$ MIC. DMSO was added to $5 \%(v / v)$ of the final volume, followed by incubating at $37^{\circ} \mathrm{C}$ for $4 \mathrm{~h}$. The suspensions were centrifuged $(8000 \mathrm{r} / \mathrm{min}, 5 \mathrm{~min})$ and washed by $0.1 \mathrm{M}$ PBS twice. Afterward, the cells were transferred into $2.5 \%(v / v)$ glutaraldehyde in $0.1 \mathrm{M} \mathrm{PBS}$ at $4{ }^{\circ} \mathrm{C}$ for another $4 \mathrm{~h}$. The cells were washed by $0.1 \mathrm{M}$ PBS three times and dehydrated in sequential graded ethanol concentrations of $30 \%, 50 \%, 80 \%, 90 \%$, and $100 \%$. Finally, the ethanol was replaced by $100 \%$ tertiary butyl alcohol. Samples were sputter-coated with gold in an ion coater for $2 \mathrm{~min}$, followed by microscopic examinations on a SEM (Tescan Vega 3 SBH, Brno, Czech).

\subsubsection{Time-Kill Analysis}

To investigate the bactericidal effects of FCEO, time-kill analysis was curved as Joray et al. [25] described. After incubating in NB medium at $37^{\circ} \mathrm{C}$ for $8 \mathrm{~h}$, bacteria were centrifuged and resuspended in sterile saline to approximately $10^{5} \mathrm{CFU} / \mathrm{mL}$. The bacterial suspension was mixed with NB medium containing $5 \%$ DMSO in the presence of FCEO at different concentrations of control, MIC and 2×MIC, respectively. The inoculums were cultured at $37^{\circ} \mathrm{C}$ with shake. Samples were taken from the culture at selected time intervals, diluted in sterile saline and cultured on NA medium. Colony-forming units were counted after incubating for $24 \mathrm{~h}$ at $37^{\circ} \mathrm{C}$.

\subsubsection{Cell Membrane Permeability}

Cell membrane permeability is expressed as the relative electric conductivity. It was measured as Kong et al. [11] described with minor modifications. Bacterial strains were incubated at $37^{\circ} \mathrm{C}$ for $8 \mathrm{~h}$, followed by centrifugation at $5000 \mathrm{r} / \mathrm{min}$ for $10 \mathrm{~min}$. The cells were washed with $5 \%$ glucose solution (containing 5\% DMSO, $v / v$ ) and centrifuged until the electric conductivities of the cells were near to that of $5 \%$ glucose. The isotonic bacteria were approximately $10^{6} \mathrm{CFU} / \mathrm{mL}$. Conductivities of essential oil added with $5 \%$ glucose at different concentrations were measured and recorded as $\mathrm{L}_{1}$. The essential oil at different concentrations completely mixed with bacterial suspension and incubated at $37^{\circ} \mathrm{C}$ for $12 \mathrm{~h}$. The conductivities were measured per hour and recorded as $\mathrm{L}_{2}$. The conductivity of bacteria in $5 \%$ glucose treated in boiling water for 5 min was marked as $\mathrm{L}_{0}$. The cell membrane permeability is calculated as the following formula:

$$
\text { Relative electric conductivity }(\%)=\frac{\left(L_{2}-L_{1}\right)}{L_{0}} \times 100 \%
$$

\subsubsection{The Integrity of Cell Membrane}

Release of cell constituents into the supernatant was carried out according to the method of Du et al. [26] with a few modifications. Tested microorganisms from $100 \mathrm{~mL}$ culture medium were collected by centrifugation for $10 \mathrm{~min}$ at $3500 \times g$, washed three times and resuspended in $0.1 \mathrm{M}$ PBS, $\mathrm{pH}$ 7.4. The cells were added into $100 \mathrm{~mL} \mathrm{NB}$ medium containing $5 \%$ DMSO and essential oil at three different concentrations of control, MIC and $2 \times$ MIC. The bacterial suspension was incubated at $37^{\circ} \mathrm{C}$ under agitation. After treatment for $0,1,2,3,4,5,6$ and 7 hours, cells were centrifuged at $3500 \times g$ and the supernatant was determined at $260 \mathrm{~nm}$ by a UV/Vis Spectrophotometer (TU-1900, Beijing, China), respectively. Correction was made for absorption of the suspension with the same PBS containing the same concentration of the oil after 2 min of contact with tested strains. The untreated cells were corrected with PBS only.

\subsection{Statistical Analysis}

All the assays were carried out triplicate. The data were recorded as mean \pm standard. A general analysis of variance (ANOVA) and Duncan's multiple range tests were performed. Values of $p<0.05$ were considered to be statistically different. 


\section{Conclusions}

To broaden the application of FCEO as a natural antimicrobial agent in the food industry, the study determined its antimicrobial activity and gave insight into its mode of action on E. coli and S. aureus as representatives from Gram-negative and Gram-positive bacteria. It demonstrates 28 compounds in essential oil which are abundant with limonene, $\gamma$-terpinene, and dodecanoic acid. During in vitro antibacterial activities tests, Gram-positive organisms seemed to be more susceptible to the oil than Gram-negative organisms, which is attributed to the structure of the cellular membrane. FCEO induces alterations in the morphology of E. coli and S. aureus. Permeability and integrity of the cell membrane tests suggest intracellular materials, including small ions, nucleic acids, and proteins, leaked when treated with FCEO at MIC and $2 \times$ MIC levels, in a dose-dependent manner.

Author Contributions: Conceptualization, M.C. and P.-L.S.; methodology, M.C., Z.-H.L. and S.-L.L.; formal analysis, Y.-S.L.; investigation, Z.-H.L.; writing-original draft preparation, Z.-H.L.; writing-review and editing, M.C.; project administration, Y.-S.L.; funding acquisition, P.-L.S.

Funding: This research was funded by National Natural Science Foundation of China (No. 31401506).

Conflicts of Interest: The authors declare no conflict of interest.

\section{References}

1. Hennekinne, J.A.; Buyser, M.L.D.; Dragacci, S. S taphylococcus aureus and its food poisoning toxins: Characterization and outbreak investigation. FEMS Microbiol. Rev. 2012, 36, 815-836. [CrossRef] [PubMed]

2. Böhme, K.; Barros-Velázquez, J.; Calo-Mata, P.; Aubourg, S.P. Antibacterial, Antiviral and Antifungal Activity of Essential Oils: Mechanisms and Applications. In Antimicrobial Compounds; Springer: Berlin, Germany, 2014; pp. 51-81. [CrossRef]

3. Prakash, B.; Shukla, R.; Singh, P.; Mishra, P.K.; Dubey, N.K.; Kharwar, R.N. Efficacy of chemically characterized Ocimum gratissimum L. essential oil as an antioxidant and a safe plant based antimicrobial against fungal and aflatoxin B 1 contamination of spices. Food Res. Int. 2011, 44, 385-390. [CrossRef]

4. Sakurada, T.; Kuwahata, H.; Katsuyama, S.; Komatsu, T.; Morrone, L.A.; Corasaniti, M.T.; Bagetta, G.; Sakurada, S. Intraplantar injection of bergamot essential oil into the mouse hindpaw: Effects on capsaicininduced nociceptive behaviors. Int. Rev. Neurobiol. 2009, 85, 237-248.

5. Saiyudthong, S.; Marsden, C.A. Acute effects of bergamot oil on anxiety-related behaviour and corticosterone level in rats. Phytother. Res. 2010, 25, 858-862. [CrossRef] [PubMed]

6. Kim, K.N.; Ko, Y.J.; Yang, H.M.; Ham, Y.M.; Roh, S.W.; Jeon, Y.J.; Ahn, G.; Kang, M.C.; Yoon, W.J.; Kim, D. Anti-inflammatory effect of essential oil and its constituents from fingered citron (Citrus medica L. var. sarcodactylis) through blocking JNK, ERK and NF- $\mathrm{BB}$ signaling pathways in LPS-activated RAW 264.7 cells. Food Chem. Toxicol. 2013, 57, 126-131. [CrossRef]

7. Russo, R.; Ciociaro, A.; Berliocchi, L.; Cassiano, M.G.V.; Rombolà, L.; Ragusa, S.; Bagetta, G.; Blandini, F.; Corasaniti, M.T. Implication of limonene and linalyl acetate in cytotoxicity induced by bergamot essential oil in human neuroblastoma cells. Fitoterapia 2013, 89, 48-57. [CrossRef]

8. Djabou, N.; Lorenzi, V.; Guinoiseau, E.; Andreani, S.; Giuliani, M.-C.; Desjobert, J.-M.; Bolla, J.-M.; Costa, J.; Berti, L.; Luciani, A.; et al. Phytochemical composition of Corsican Teucrium essential oils and antibacterial activity against foodborne or toxi-infectious pathogens. Food Control 2013, 30, 354-363. [CrossRef]

9. Van Vuuren, S.F.; Viljoen, A.M. Antimicrobial activity of limonene enantiomers and 1,8-cineole alone and in combination. Flavour. Fragr. J. 2007, 22, 540-544. [CrossRef]

10. Shakeri, A.; Khakdan, F.; Soheili, V.; Sahebkar, A.; Rassam, G.; Asili, J. Chemical composition, antibacterial activity, and cytotoxicity of essential oil from Nepeta ucrainica L. spp. kopetdaghensis. Ind. Crop. Prod. 2014, 58, 315-321. [CrossRef]

11. Kong, M.; Chen, X.G.; Liu, C.S.; Liu, C.G.; Meng, X.H.; Yu, L.J. Antibacterial mechanism of chitosan microspheres in a solid dispersing system against E. coli. Colloid Surf. B-Biointerfaces 2008, 65, 197-202. [CrossRef] [PubMed] 
12. Guo, J.-J.; Gao, Z.-P.; Xia, J.-P.; Ritenour, M.A.; Li, G.-Y.; Shan, Y. Comparative analysis of chemical composition, antimicrobial and antioxidant activity of citrus essential oils from the main cultivated varieties in China. LWT-Food Sci. Technol. 2018, 97, 825-839. [CrossRef]

13. Ghabraie, M.; Vu, K.D.; Tata, L.; Salmieri, S.; Lacroix, M. Antimicrobial effect of essential oils in combinations against five bacteria and their effect on sensorial quality of ground meat. LWT-Food Sci. Technol. 2016, 66, 332-339. [CrossRef]

14. Diao, W.-R.; Hu, Q.-P.; Zhang, H.; Xu, J.-G. Chemical composition, antibacterial activity and mechanism of action of essential oil from seeds of fennel (Foeniculum vulgare Mill.). Food Control 2014, 35, 109-116. [CrossRef]

15. Cox, S.D.; Mann, C.M.; Markham, J.L.; Gustafson, J.E.; Warmington, J.R.; Wyllie, S.G. Determining the Antimicrobial Actions of Tea Tree Oil. Molecules 2001, 6, 87-91. [CrossRef]

16. Sharma, A.; Bajpai, V.K.; Baek, K. Determination of Antibacterial Mode of Action of Allium sativum Essential Oil against Foodborne Pathogens Using Membrane Permeability and Surface Characteristic Parameters. J. Food Saf. 2013, 33, 197-208. [CrossRef]

17. Bajpai, V.K.; Baek, K.H.; Sun, C.K. Control of Salmonella in foods by using essential oils: A review. Food Res. Int. 2012, 45, 722-734. [CrossRef]

18. Burt, S. Essential oils: Their antibacterial properties and potential applications in foods-A review. Int. J. Food Microbiol. 2004, 94, 223-253. [CrossRef]

19. Kohanski, M.A.; Dwyer, D.J.; Collins, J.J. How antibiotics kill bacteria: From targets to networks. Nat. Rev. Microbiol. 2010, 8, 423-435. [CrossRef]

20. Bajpai, V.K.; Sharma, A.; Baek, K.H. Antibacterial mode of action of Cudrania tricuspidata fruit essential oil, affecting membrane permeability and surface characteristics of food-borne pathogens. Food Control 2013, 32, 582-590. [CrossRef]

21. Bakkali, F.; Averbeck, S.; Averbeck, D.; Idaomar, M. Biological effects of essential oils-A review. Food Chem. Toxicol. 2008, 46, 446-475. [CrossRef]

22. Wu, Z.; Li, H.; Yang, Y.; Zhan, Y.; Tu, D. Variation in the components and antioxidant activity of Citrus medica L. var. sarcodactylis essential oils at different stages of maturity. Ind. Crop. Prod. 2013, 46, 311-316. [CrossRef]

23. Liu, X.; Zhong, S.; Wu, K.; Yu, H.; Chai, X. Antimicrobial activity in the vapour phase of a combination of cinnamon and clove essential oils. Food Chem. 2009, 116, 982-989.

24. De Silveira, S.M.; Luciano, F.B.; Fronza, N.; Cunha, A., Jr.; Scheuermann, G.N.; Vieira, C.R.W. Chemical composition and antibacterial activity of Laurus nobilis essential oil towards foodborne pathogens and its application in fresh Tuscan sausage stored at $7{ }^{\circ} \mathrm{C}$. LWT-Food Sci. Technol. 2014, 59, 86-93. [CrossRef]

25. Joray, M.B.; del Rollán, M.R.; Ruiz, G.M.; Palacios, S.M.; Carpinella, M.C. Antibacterial activity of extracts from plants of central Argentina-isolation of an active principle from Achyrocline satureioides. Planta Med. 2011, 77, 95-100. [CrossRef] [PubMed]

26. Du, W.; Sun, C.; Liang, Z.; Han, Y.; Yu, J. Antibacterial activity of hypocrellin A against Staphylococcus aureus. World J. Microbiol. Biotechnol. 2012, 28, 3151-3157. [CrossRef] [PubMed]

Sample Availability: Samples of the essential oils are available from the authors.

(C) 2019 by the authors. Licensee MDPI, Basel, Switzerland. This article is an open access article distributed under the terms and conditions of the Creative Commons Attribution (CC BY) license (http://creativecommons.org/licenses/by/4.0/). 